ISSN 1330-7142

$U D K=631.51+631.416 .1: 632.3$

DOI: $10.18047 /$ poljo.25.1.4

\title{
THE IMPACT OF DIFFERENT CONSERVATION SOIL TILLAGE AND NITROGEN FERTILIZATION ON WHEAT GRAIN INFECTION WITH Fusarium sp.
}

\author{
Vrandečić, K., Jug, D., Ćosić, J., Ilić, J., Jug, I. \\ Original scientific paper \\ Izvorni znanstveni članak
}

\begin{abstract}
SUMMARY
The effect of different conservation soil tillage (CST) treatments and different level of nitrogen fertilization on Fusarium wheat grain infection on two locations are presented in this paper. The research was conducted on winter wheat with different soil tillage treatments: conventional tillage to $30 \mathrm{~cm}$ depth, subsoiling to $35-40 \mathrm{~cm}$ depth, chiselling up to $25 \mathrm{~cm}$, disk-harrowing to $10-15 \mathrm{~cm}$ and no-tillage, without any tillage treatments and three different nitrogen rates (N1 - amount reduced by $30 \%$ of recommended; $N 2$ - according to standard recommendation and $\mathrm{N} 3$ - amount increased by $30 \%$ of recommended). The occurrence of Fusarium species was determined in all the tested variants of tillage and fertilization treatments. The effect of reduced fertilization (N1) on Fusarium sp. grain infection in all tillage treatments was statistically lower in comparison with other (N2 and N3) nitrogen treatments. The lowest percentage of wheat grains infected with Fusarium sp. was recorded in conventional tillage on location Magadenovac and no tillage treatments on location Cacinci.
\end{abstract}

Key words: conservation soil tillage, nitrogen fertilization, wheat grain infection, Fusarium sp.

\section{INTRODUCTION}

Conservation soil tillage (CST) is one of the most prospect and prominent soil tillage technology which can prevail many negative effects arising from application of conventional crop production and especially conventional soil tillage technology (Jug et al., 2017) in different agroecological conditions and in expecting climate change conditions (Jug et al., 2018). Except positive effect of CST, and because of specific conditions of that technology (especially crop residue management), some negative events can appear in production of wheat causing diversification in wheat yields and yield components (Jug et al., 2011). Fusarium head blight (FHB) caused by the fungal plant pathogens from genus Fusarium is destructive disease of wheat in most wheat-growing regions around the world and in all soil tillage systems for wheat cropping. The disease causes yield loss, low test weights, low seed germination and contamination of grain with mycotoxins. Several species are capable of causing FHB. In Croatia the species most commonly encountered is Fusarium graminearum.

Agricultural practices are very important factors for the control of Fusarium survival (Leplat et al., 2013) since pathogen survive on plant residues left from the previous crop (Blandino et al., 2010) and weeds (Poštić et al., 2012). An appropriate crop rotation and tillage system can limit the risk of FHB development (Fernandez et al., 2008). Burying infested crop residues deeper in the soil is commonly used for Fusarium inoculum reduction. Many studies have evaluated the effects of nitrogen application rates on FHB (Pageau et al., 2008; Yoshida et al., 2008; Burgt et al., 2011). The research presented in this paper was set up to study the effect of different CST treatments and different level of nitrogen fertilization on Fusarium wheat grain infection on two locations.

\section{MATERIAL AND METHODS}

Prof. Karolina Vrandečić, Ph.D., Prof. Danijel Jug, Ph.D. (djug@fazos.hr), Prof. Jasenka Ćosić, Ph.D., Assist. Prof. Jelena Ilić, Ph.D., Prof. Irena Jug, Ph.D. - Josip Juraj Strossmayer University of Osijek, Faculty of Agrobiotechnical Sciences Osijek, Vladimira Preloga 1, 31000 Osijek, Croatia 


\section{Field experiment}

Stationary field experiments were established at two experimental stations (two different soil types, Table 1) in eastern Croatia in 2009. An experiment on Stagnosols soil type was established at location Cacinci (Long. 17.86336 E, Lat.45.61316 N) and on Gleysols at location Magadenovac (Long. 18.70648 E, Lat.45.55555 N). Data for winter wheat (cv. Lucija), presented in this paper were collected in the years 2013-2014. The winter wheat was grown in five-year crop rotation with pre-crop maize. The research was conducted with five different soil tillage treatments (main factor, TT-tillage treatment), the size of each basic soil tillage plot was $600 \mathrm{~m}^{2}$. Three different nitrogen rates (sub-factor N) was used, with basic nitrogen fertilization plot size of $195 \mathrm{~m}^{2}$. The experiment was set up on RCBD design in three repetitions. The following five TT were applied: Conventional tillage (CT) based on autumn mouldboard ploughing to $30 \mathrm{~cm}$ depth and four CST treatment with different crop residue cover on soil surface (Table 2); Subsoiling (SS) to 35-40 cm depth, Chiselling (CH) up to 25 $\mathrm{cm}$, Disk-harrowing (DH) to $10-15 \mathrm{~cm}$ and No-tillage (NT) without any tillage treatments. The crop residues cover was measured using Line-transect method (Morrison et al., 1993). Nitrogen fertilization treatment had three levels of applied nitrogen: $\mathrm{N} 1$ - amount reduced by $30 \%$ of recommended $(80 \mathrm{~kg}$ $\left.\mathrm{ha}^{-1} \mathrm{~N}+110 \mathrm{~kg} \mathrm{ha}^{-1} \mathrm{~K}_{2} \mathrm{O}+100 \mathrm{~kg} \mathrm{ha}^{-1} \mathrm{P}_{2} \mathrm{O}_{5}\right), \mathrm{N} 2$ - according to recommendation $\left(115 \mathrm{~kg} \mathrm{ha}^{-1} \mathrm{~N}+110\right.$ $\left.\mathrm{kg} \mathrm{ha}^{-1} \mathrm{~K}_{2} \mathrm{O}+100 \mathrm{~kg} \mathrm{ha}^{-1} \mathrm{P}_{2} \mathrm{O}_{5}\right), \mathrm{N} 3$ - amount increased by $30 \%$ of recommended $\left(150 \mathrm{~kg} \mathrm{ha}^{-1} \mathrm{~N}+110\right.$ $\mathrm{kg} \mathrm{ha}^{-1} \mathrm{~K}_{2} \mathrm{O}+100 \mathrm{~kg} \mathrm{ha}^{-1} \mathrm{P}_{2} \mathrm{O}_{5}$ ). Except for the soil tillage and nitrogen fertilization, all the other technology measures such as: sowing, $\mathrm{P}$ and $\mathrm{K}$ fertilization, pests control, machinery and equipment used were identical in all the treatments.

\section{Laboratory analysis}

Health analysis of wheat grains was done by deep freezing method. Wheat grains were washed under running water, disinfected for $30 \mathrm{sec}$. with $96 \%$ ethanol and washed in distilled water three times. For each sample 3x100 grains were analysed and average value of diseases incidence calculated for each sample in percentages. Petri dishes with moisture filter paper were kept in chamber for $24 \mathrm{~h}$ at $20^{\circ} \mathrm{C}$ and light regime 12 hours day $/ 12$ hours night, then $24 \mathrm{~h}$ in freezer at $-18^{\circ} \mathrm{C}$ and finally 12 days in chamber on $20^{\circ} \mathrm{C}$. The examination was performed after 14 days with stereo microscope (Olympus SZX9) and microscope (Olympus BX41). Grain infection with Fusarium was evaluated for each sample for 3x100 grains by determining mycelia development on grain surface with stereo microscope. If necessary, mycelia developed on wheat grain was transferred to potato dextrose agar (PDA) for further determination and growing pure fungal cultures (Vrandečić et al., 2013). Identification to genus level was done based on fungal morphological characteristics.

All collected data were statistically processed with SAS software (1999).

\section{Experimental site conditions}

According to Croatian Meteorological and hydrological service (DHMZ, Jug et al., 2017), (Table 3) the precipitation amounts from October 2013 to July 2014 (period when the experiment was conducted) was $662 \mathrm{~mm}$ (Cacinci) and 591 (Magadenovac). In May (heading and flowering period) the precipitations were $160 \mathrm{~mm}$ (Cacinci) and 140 (Magadenovac) whereas in June 64 (Cacinci) and $62 \mathrm{~mm}$ (Magadenovac).

Table 1. Soil chemical composition on the experimental sites. Tablica 1. Kemijski sastav tla na eksperimentalnim površinama.

\begin{tabular}{|l|c|c|c|c|c|c|}
\hline $\begin{array}{l}\text { Experimental site } \\
\text { Pokusna površina }\end{array}$ & $\begin{array}{c}\mathrm{pH} \\
\left(\mathrm{H}_{2} \mathrm{O}\right)\end{array}$ & $\begin{array}{c}\mathrm{pH} \\
(\mathrm{KCl})\end{array}$ & $\begin{array}{c}\mathrm{P}_{2} \mathrm{O}_{5} \\
\left(\mathrm{mg} 100 \mathrm{~g}^{-1}\right)\end{array}$ & $\begin{array}{c}\mathrm{K}_{2} \mathrm{O} \\
\left.(\mathrm{mg} \mathrm{100} \mathrm{g})^{-1}\right)\end{array}$ & $\begin{array}{c}\mathrm{Humus} \\
(\%)\end{array}$ & $\begin{array}{c}\mathrm{Hy}^{*} \\
\left(\mathrm{cmol} \mathrm{kg}^{-1}\right)\end{array}$ \\
\hline Cacinci & 5.09 & 4.03 & 6.2 & 12.7 & 2.4 & 5.1 \\
\hline Magadenovac & 5.29 & 4.27 & 17.2 & 22.7 & 1.3 & 4.4 \\
\hline
\end{tabular}

Soil hydrolytic acidity 
Table 2. Crop residue cover on soil surface related to soil tillage treatment and experimental sites. Tablica 2. Pokrivenost površine tla na različitim sustavima obrade tla i eksperimentalnim površinama.

\begin{tabular}{|l|c|c|c|c|c|}
\hline \multirow{2}{*}{$\begin{array}{l}\text { Experimental site } \\
\text { Pokusna površina }\end{array}$} & \multicolumn{5}{|c|}{ Crop residue soil cover (\%) } \\
\cline { 2 - 6 } & CT & SS & CH & DH & NT \\
\hline Cacinci & 4 & 37 & 53 & 30 & 99 \\
\hline Magadenovac & 5 & 46 & 57 & 31 & 99 \\
\hline
\end{tabular}

Table 3. Average weather conditions in the experimental period (2013/2014) and long-term average (19842012) on both localities.

Tablica 3. Prosječne vremenske prilike tijekom razdoblja istraživanja (2013./2014.) i višegodišnje prosječne vremenske prilike (1984.-2012.) na obje lokacije istraživanja.

\begin{tabular}{|c|c|c|c|c|c|c|c|c|c|c|c|}
\hline & $X$ & XI & XII & $\mathrm{I}$ & II & III & IV & $\mathrm{V}$ & VI & VII & $\sum / X$ \\
\hline \multicolumn{12}{|c|}{$\begin{array}{l}\text { Average long-term and months precipitations }(\mathrm{mm}) \\
\text { Prosječna mjesečna i godišnja količina oborina }(\mathrm{mm})\end{array}$} \\
\hline \multicolumn{12}{|c|}{ Cacinci } \\
\hline 1984-2012 & 70.3 & 73.8 & 64.9 & 55.7 & 41.4 & 53.7 & 62.6 & 75.1 & 95.0 & 69.4 & 661.9 \\
\hline $2013 / 2014$ & 41.9 & 101.7 & 1.1 & 40.4 & 64.5 & 48.7 & 98.2 & 159.7 & 64.0 & 79.3 & 699.5 \\
\hline \multicolumn{12}{|c|}{ Magadenovac } \\
\hline 1984-2012 & 61.3 & 64.9 & 55.8 & 49.7 & 39.4 & 46.3 & 57.3 & 67.7 & 85.5 & 62.6 & 590.5 \\
\hline $2013 / 2014$ & 28.6 & 66.9 & 0.5 & 51.8 & 75.8 & 24.9 & 69.1 & 139.2 & 62.4 & 82.0 & 601.2 \\
\hline \multicolumn{12}{|c|}{$\begin{array}{l}\text { Average month and year air temperature }\left({ }^{\circ} \mathrm{C}\right) \\
\text { Prosječna mjesečna i godišnja temperatura zraka }\left({ }^{\circ} \mathrm{C}\right)\end{array}$} \\
\hline \multicolumn{12}{|c|}{ Cacinci } \\
\hline $1984-2012$ & 11.4 & 6.0 & 1.7 & 0.6 & 1.8 & 6.3 & 11.6 & 16.3 & 19.7 & 21.8 & 9.7 \\
\hline $2013 / 2014$ & 13.6 & 7.6 & 2.7 & 4.3 & 5.5 & 9.6 & 12.8 & 15.4 & 20.3 & 21.8 & 11.4 \\
\hline \multicolumn{12}{|c|}{ Magadenovac } \\
\hline $1984-2012$ & 11.6 & 5.9 & 1.3 & 0.3 & 1.8 & 6.5 & 12.0 & 17.0 & 20.3 & 22.3 & 9.9 \\
\hline $2013 / 2014$ & 13.3 & 7.6 & 1.8 & 3.6 & 5.2 & 9.8 & 13.2 & 15.7 & 20.4 & 22.0 & 11.3 \\
\hline
\end{tabular}

(Source: Jug et al., 2017)

\section{RESULTS AND DISCUSSION}

The presence of Fusarium species was determined in all tested treatments of soil tillage and fertilization. On Magadenovac, lower level of nitrogen (N1) reduced the grain infection with Fusarium species in comparison with other nitrogen treatments in three different tillage systems (CT, DH and NT) (Table 4). The highest percentage of wheat grains infected with Fusarium sp. $14.00 \%$ was increased by $30 \%$ (N3) on subsoiling treatment (SS) and N application. Although, the percentage of the infection by Fusarium on SS and $\mathrm{CH}$ tillage treatment was higher at N1 than at N2, these differences were not statistically significant. On location Cacinci (Table 4) effect of reduced fertilization (N1) on Fusarium sp. grain infection in all types of soil tillage was statistically lower in comparison with other ( $\mathrm{N} 2$ and $\mathrm{N} 3)$ nitrogen treatments.

Influence of nitrogen fertilization and tillage system on FHB incidence should not be monitored separately from all other factors (weather conditions, agrotechnical measures, genotype, amount of inoculum of plant pathogen, aggressivity and pathogenicity of Fusarium spp.) which influence the plant disease incidence. Due to that fact there are different opinions on influence of fertilization and tillage on Fusarium incidence.

Table 4. Effect of nitrogen fertilization on Fusarium sp. wheat grain infection (\%) on different soil tillage treatments on both localities. 
Tablica 4. Utjecaj gnojidbe dušikom na infekciju zrna kukuruza vrstama Fusarium (\%) na različitim sustavima obrade tla na oba lokaliteta.

\begin{tabular}{|l|c|c|c|c|}
\hline \multirow{2}{*}{$\begin{array}{l}\text { Soil tillage treatment } \\
\text { Sustav obrade tla }\end{array}$} & $\mathrm{N} 1$ & $\mathrm{~N} 2$ & $\mathrm{~N} 3$ & LSD 0.05 \\
\cline { 2 - 5 } & \multicolumn{3}{|c|}{$\begin{array}{c}\text { Nitrogen level fertilization } \\
\text { Razina gnojidbe dušikom }\end{array}$} \\
\hline CT & $1.33 \mathrm{c}$ & $3.00 \mathrm{~b}$ & $9.33 \mathrm{a}$ & 0.75 \\
\hline SS & $7.00 \mathrm{~b}$ & $6.33 \mathrm{~b}$ & $14.00 \mathrm{a}$ & 2.40 \\
\hline CH & $9.33 \mathrm{a}$ & $8.68 \mathrm{a}$ & $9.00 \mathrm{a}$ & 3.77 \\
\hline DH & $4.68 \mathrm{~b}$ & $8.00 \mathrm{a}$ & $10.33 \mathrm{a}$ & 2.76 \\
\hline NT & $5.33 \mathrm{~b}$ & $6.33 \mathrm{a}$ & $7.00 \mathrm{a}$ & 1.51 \\
\hline \multicolumn{5}{|c|}{ Cacinci } \\
\hline CT & $2.66 \mathrm{~b}$ & $9.00 \mathrm{a}$ & $9.33 \mathrm{a}$ & 2.44 \\
\hline SS & $3.00 \mathrm{~b}$ & $9.33 \mathrm{a}$ & $10.33 \mathrm{a}$ & 1.51 \\
\hline CH & $7.00 \mathrm{~b}$ & $9.00 \mathrm{a}$ & $10.67 \mathrm{a}$ & 3.16 \\
\hline DH & $6.33 \mathrm{~b}$ & $7.00 \mathrm{a}$ & $10.33 \mathrm{a}$ & 4.59 \\
\hline NT & $3.00 \mathrm{~b}$ & $6.67 \mathrm{a}$ & $9.00 \mathrm{a}$ & 3.16 \\
\hline
\end{tabular}

Conventional tillage (CT), Subsoiling (SS), Chiseling (CH), Disk-harrowing (DH), No-tillage (NT), Nitrogen fertilization: $\mathrm{N} 1$ - amount reduced by $30 \%$ according to recommendation, N2 - according to recommendation, N3 - amount increased by $30 \%$ according to recommendation

a,b,c - different letters mark statistically significant difference according to Duncan's Multiple Range Test at the level $\mathrm{P} \leq 0.05$

Results of our fertilization influence research of in different soil tillage systems on Magadenovac and Cacinci locations showed that increased nitrogen fertilization resulted in higher infection of grains with Fusarium sp. This statement is supported by the results of Agrios (1997) where high concentration of nitrogen increases plant disease susceptibility. High concentration of nitrogen in soil supported incidence of wheat FHB (Ivashenko and Nazarovskaya, 1990; Lemmens et al. 2004; Milev et al. 2008; Suproniene et al., 2012). Burgt et al. (2011) after two years of the experiment concluded that increasing N content is not recommended due to favouring wheat Fusarium infection. In contrary, Fauzi and Paulitz (1994) and Yoshida et al. (2008) claimed that nitrogen amount did not influence infection of wheat with Fusarium sp.

Nitrogen fertilization with $\mathrm{N}$ amount reduced by $30 \%$ in conventional tillage (CT) on location Magadenovac resulted in the lowest number of infected grains (1.33\%) (Table 5). For nitrogen fertilization according to recommendation, significant statistical difference was determined between conventional tillage (CT) with the lowest number of infected grains (3\%) and other investigated treatments. Nitrogen fertilization increased by $30 \%$ caused Fusarium incidence between $7 \%$ (NT) and 14\% (SS) of the infected grains. Infection level with Fusarium sp. in the reduced tillage system (SS, $\mathrm{CH}, \mathrm{DH}$ and $\mathrm{NT}$ ) was significantly higher than on $\mathrm{CT}$ in $\mathrm{N} 1$ and $\mathrm{N} 2$ nitrogen treatments.

Statistical difference in different tillage system was determined on location Cacinci only in nitrogen fertilization with $\mathrm{N}$ amount reduced by $30 \%$ (Table 5). The lowest percentage of wheat grains infected with Fusarium sp. was recorded on no-tillage (NT) at nitrogen fertilization according to recommendation and at nitrogen fertilization increased by $30 \%$.

Table 5. Effect of soil tillage on Fusarium sp. maize grain infection (\%) on different nitrogen fertilization treatments on both localities.

Tablica 5. Utjecaj obrade tla na infekciju zrna kukuruza vrstama Fusarium (\%) na različitim tretmanima gnojidbe dušikom na oba lokaliteta.

\begin{tabular}{|c|c|c|c|c|c|c|}
\hline \multirow{2}{*}{$\begin{array}{l}\text { Nitrogen level } \\
\text { fertilization } \\
\text { Razina gnojidbe } \\
\text { dušikom }\end{array}$} & CT & SS & $\mathrm{CH}$ & DH & NT & LSD 0.05 \\
\hline & \multicolumn{5}{|c|}{$\begin{array}{l}\text { Soil tillage treatment } \\
\text { Sustav obrade tla }\end{array}$} & \\
\hline \multicolumn{7}{|c|}{ Magadenovac } \\
\hline N1 & $1.33 \mathrm{~d}$ & $7.00 \mathrm{~b}$ & $9.33 \mathrm{a}$ & $4.68 \mathrm{c}$ & $5.33 \mathrm{c}$ & 0.66 \\
\hline $\mathrm{N} 2$ & $3.00 \mathrm{c}$ & $6.30 \mathrm{~b}$ & $8.67 \mathrm{a}$ & $8.00 \mathrm{ab}$ & $6.33 \mathrm{~b}$ & 1.40 \\
\hline N3 & $9.33 \mathrm{bc}$ & $14.00 \mathrm{a}$ & $9.00 \mathrm{bc}$ & $10.33 \mathrm{~b}$ & $7.00 \mathrm{c}$ & 2.33 \\
\hline
\end{tabular}




\begin{tabular}{|l|l|l|l|l|l|l|}
\hline N1 & $2.66 \mathrm{~b}$ & $3.00 \mathrm{~b}$ & $7.00 \mathrm{a}$ & $6.33 \mathrm{a}$ & $3.00 \mathrm{~b}$ & 2.29 \\
\hline $\mathrm{N} 2$ & $9.00 \mathrm{a}$ & $9.33 \mathrm{a}$ & $9.00 \mathrm{a}$ & $7.00 \mathrm{a}$ & $6.67 \mathrm{a}$ & 3.01 \\
\hline $\mathrm{N} 3$ & $9.33 \mathrm{a}$ & $10.33 \mathrm{a}$ & $10.67 \mathrm{a}$ & $10.33 \mathrm{a}$ & $9.00 \mathrm{a}$ & 2.78 \\
\hline
\end{tabular}

Conventional tillage (CT), Subsoiling (SS), Chiseling (CH), Disk-harrowing (DH), No-tillage (NT), Nitrogen fertilization: $\mathrm{N} 1$ - amount reduced by $30 \%$ according to recommendation, N2 - according to recommendation, N3 - amount increased by $30 \%$ according to recommendation

a,b,c,d - different letters mark statistically significant difference according to Duncan's Multiple Range Test at the level $\mathrm{P} \leq$ 0.05

Soil tillage had influence on Fusarium sp. incidence of wheat grain while infection percentage with Fusarium sp. was higher on the reduced tillage with N1 and N2 nitrogen level. Vrandečić et al. (2013), determined higher number of grains infected with Fusarium sp. in no-tillage and reduced tillage systems in the two-year research (2008 and 2009) of influence of soil tillage and fertilization on wheat grain infection with fungi. Tillage systems had significant influence on FHB frequency, but no effect on infection with other fungal genera. However, nitrogen treatments did not show significant influence on Fusarium population. Incorporation of infected plant residues, which are one of the main sources of Fusarium infection, reduced inoculum amount (Leplat et al., 2013) deep into the ground. It can be expected that in conventional tillage infection percentage is lower than in reduced tillage. Hofgaard et al. (2016) also determined that soil tillage and incorporation of plant residue reduced inoculum amount of Fusarium sp.

According to Lori et al. (2009) no-tillage system can result in higher Fusarium incidence, but optimal climate conditions for disease incidence are probably more important than tillage and fertilization systems. Soil tillage treatments had no significant influence on Fusarium infection level on location Cacinci probably due to higher precipitation during the vegetation period (Table 3). Conventional tillage recorded lower infection percentage than conservation tillage due to a higher amount of harvested residues on Magadenovac location.

Environment is the most important factor influencing Fusarium disease incidence (Fernandez et al. 2005; Bíliková and Hudec, 2013). However, in years with average or high levels of disease, farming system can affect disease severity. Since Fusarium is highly adaptable to different, often extreme, environment conditions wheat head infection favours wet conditions in flowering, i.e. in May and June. In our research the amount of rain in May and June favoured Fusarium infections. Temperatures in May were little lower compared to long-term average, i.e. the period was determined to be colder and June was marked as warmer than year average (DHMZ data, Jug et al., 2017).

Some of Fusarium species produce mycotoxins. However, according to Baliukoniene et al. (2011) in no-tillage there is no significant mycotoxin production. Trichothecene mycotoxin type B deoxynivalenol (DON) could be regarded as an indicator of the overall mycotoxin contamination (Lacko-Bartosova et al., 2017). Tillage systems had no significant influence on Fusarium infection level, but they had indirect effect on mycotoxin content depending on years (Suproniene et al., 2012). During the 4-year experiment, nitrogen fertilization had no significant effect on deoxynivlenol (DON) content of barley (Pageau et al., 2008). The organic crop rotation and conventional crop rotation does not influence DON content in winter wheat grain (Vanova et al., 2008). CST system is considered to be cause of epidemic FHB infection in Central America (Dill-Macky and Jones, 2000), due to production system where maize is produced in rotation with wheat.

There is no simple solution for Fusarium incidence on wheat, but knowledge about agroecological conditions and cultural practice which influence infection and disease development in some particular area are the key for potential risk estimate of disease incidence and development of effective strategy against this pathogen. From the agroecological point of view a reduced tillage has several advantages (increased microbiological activity of soil, increased biological diversity as fungi, bacteria, nematodes, earthworms, etc.) and if disease incidence in some areas is not significant this soil tillage should be implemented. Biological diversity is the key of soil health preservation. Implementation of reduced tillage provides maintenance of soil health being more important than disease incidence at lower intensity. Holistic approach to crop systems and plant health management may provide the solution to disease problems.

\section{CONCLUSION}


Fusarium head blight on cereals occurs every year all around the world and there is no simple solution to reduce it. Different strategies of plant protection should be applied including agrotechnical measures (crop rotation, soil tillage system, nitrogen fertilization). In this research the presence of Fusarium species was determined in all the tested tillage and fertilization treatments. The effect of reduced nitrogen fertilization on Fusarium sp. grain infection in all tillage treatments was statistically lower in comparison with other nitrogen treatments. Implementation of conservation soil tillage provides biological diversity and soil health being more important than disease incidence at lower intensity.

\section{REFERENCES}

1. Agrios, G. (1997). Plant Pathology, fourth ed. Academic Press, New York, 635.

2. Baliukoniene, V., Bakutis, B., Januskeviciene, G. \& Miseikiene, R. (2011). Fungal contamination and Fusarium mycotoxins in cereals grown in different tillage systems. Journal of Animal and Feed Sciences, 20, 637-647.

3. Bíliková, J. \& Hudec, K. (2013). Incidence of Fusarium head blight on winter wheat in ecological and integrated farming system. Acta Fytotechnica et Zootechnica, 16(2), 28-32.

4. Blandino, M., Pilati, A., Reyneri, A. \& Scudellari, D. (2010). Effect of maize crop residue density on Fusarium head blight and on deoxynivalenol contamination of common wheat grains. Cereal Research Communications, 38(4), 550-559. https://doi.org/10.1556/crc.38.2010.4.12

5. Dill-Macky, R. \& Jones, R. K. (2000). The effect of previous crop residues and tillage on Fusarium head blight of wheat. Plant Disease. 84(1), 71-76. https://doi.org/10.1094/PDIS.2000.84.1.71

6. Fauzi, M. T. \& Paulitz, T. C. (1994). The effects of plant growth regulators and nitrogen on Fusarium head blight of the spring wheat cultivar Max. Plant Disease, 78, 289-292. https://doi.org/10.1094/PD-78-0289

7. Fernandez, M. R., Huber, D., Basnyat, P. \& Zentner, R. P. (2008). Impact of agronomic practices on populations of Fusarium and other fungi in cereal and noncereal crop residues on the Canadian Prairies. Soil and Tillage Research, 100(1-2), 60-71. https://doi.org/10.1016/j.still.2008.04.008.

8. Fernandez, M. R., Selles, F., Gehl, D., DePauw, R. M. \& Zentner, R. P. (2005). Crop production factors associated Fusarium head blight in spring wheat in Eastern Saskatchewan. Crop Science, 45(5), 1908-1916.

9. Hofgaard, I. S., Seehusen, T., Aamot, H. U., Riley, H., Razzaghian, J., Le, V. H., Hejlkrem, A. G. R., Dill-Macky, R. \& Brodal, G. (2016). Inoculum potential of Fusarium spp. relates to tillage and straw management in Norwegian fields of spring oats. Frontiers in Microbiology, 7, Article 556, 1-15. https://doi.org/10.3389/fmicb.2016.00556

10. Ivashenko, V. G. \& Nazarovskaya, L. A. (1990). Characteristics of the ascomycetous stage of fusarium head blight pathogen of different crops in Krasnodar Krai. Reports of the All-Union Academy of Agricultural Sciences, 12, 11-14.

11. Jug, I., Jug, D., Sabo, M., Stipesevic, B. \& Stosic, M. (2011). Winter wheat yield and yield components as affected by soil tillage systems. Turkish Journal of Agriculture and Forestry, 35(1), 1-7. https://doi.org/10.3906/tar-0909-376

12. Jug, D., Jug, I., Vukadinović, V., Đurđević, B., Stipešević, B. \& Brozović, B. (2017). Conservation soil tillage as a measure for climate change mitigation. University textbook (In Croatian). Croatian Soil Tillage Research Organization, Osijek, Croatia.

13. Jug, D., Jug, I., Brozović, B., Vukadinović, V., Stipešević, B. \& Đurđević, B. (2018). The role of conservation agriculture in mitigation and adaptation to climate change. Poljoprivreda, 24(1), 3544. https://doi.org/10.18047/poljo.24.1.5

14. Lacko-Bartošová, M., Remža, J. \& Lacko-Bartošová, L. (2017). Fusarium mycotoxin contamination and co-occurrence in Slovak winter wheat grains. Zemdirbyste-Agriculture, 104(2), 173-178. https://doi.org/10.13080/z-a.2017.104.022

15. Lemmens, M., Haim, K., Lew, H. \& Ruckenbauer, P. (2004). The effect of nitrogen fertilization on Fusarium head blight development and deoxynivalenol contamination in wheat. Journal of Phytopathology, 152(1), 1-8. https://doi.org/10.1046/j.1439-0434.2003.00791.x 
16. Leplat, J., Friberg, H., Abid, M. \& Steinberg, C. (2013). Survival of Fusarium graminearum the causal agent of Fusarium head blight. A review. Agronomy for Sustainable Development, 33(1), 97-111. https://doi.org/10.1007/s13593-012-0098-5

17. Lori, G. A., Sisterna, M. N., Sarandon, S. J., Rizzo, I. \& Chidichimo, H. (2009). Fusarium head blight in wheat: impact of tillage and other agronomic practices under natural infection. Crop Protection, 28(6), 495-502. http://doi.org/10.1016/j.cropro.2009.01.012

18. Milev, G., Tonev, T. K. \& Kiryakova, V. (2008). Influence of some agronomy factors on spike components after rare incidence of Fusarium head blight epiphytoty of winter wheat. Bulgarian Journal of Agricultural Science, 14(4), 410-416.

19. Morrison, J. E., Huang, C. H., Lightle, D. T. \& Daughtry, C. S. T. (1993). Residue measurement techniques. Journal of Soil and Water Conservation 48(6), 478-483.

20. Pageau, D., Lafond, J., Lajeunesse, J. \& Savard, M. E. (2008). Impact du precedent cultural et de la ferilization azotée sur la teneur on dèsoxynivalénol chez l'orge. Canadian Journal of Plant Pathology, 30(3), 397-403. https://doi.org/10.1080/07060660809507537

21. Poštić, J., Ćosić, J., Vrandečić, K., Jurković, D., Saleh, A. A. \& Leslie, J. F. (2012). Diversity of Fusarium Species Isolated from Weeds and Plant Debris in Croatia. Journal of PhytopathologyPhytopathologische Zeitschrift, 160(2), 76-81. https://doi.org/10.1111/j.1439-0434.2011.01863.x

22. SAS/STAT (1999). User's guide, version 8. Cary: SAS Institute; 1999.

23. Supronienè, S., Mankevičienè, A., Kadžienè, G., Kačergius, A., Feiza, V., Feizienè, D., Semaškienè, R., Dabkevičius, Z. \& Kęstutis, T. (2012). The impact of tillage and fertilization on Fusarium infection and mycotoxin production in wheat grains. Žemdirbyste Agriculture, 99(3), 265-272.

24. Váňová, M., Klem, K., Míša, P., Matušinsky, P., Hajšlová, J. \& Lancová, K. (2008). The content of Fusarium mycotoxins, grain yield and quality of winter wheat cultivars under organic and conventional cropping systems. Plant Soil and Environment, 54(9), 395-402. https://doi.org/10.17221/411-PSE

25. Van der Burgt, G. J. H. M., Timmermans, B. G. H., Scholberg, J. M. S. \& Osman, A. M. (2011). Fusarium head blight and deoxynivalenol contamination in wheat as affected by nitrogen fertilization. NJAS-Wageningen Journal of Life Sciences, 58(3-4), 123-129. https://doi.org/10.1016/j.njas.2011.09.005

26. Vrandečić, K., Jug, D., Ćosić, J., Stošić, M. \& Ilić, J. (2013). The impact of tillage and fertilization on wheat grain infection. In 2nd International Scientific Conference, Soil and Crop Management: Adaptation and Mitigation of Climate Change, 26-28 September, 2013, Osijek, Croatia (pp. 296-301). Croatian Soil Tillage Research Organization (CROSTRO).

27. Yoshida, M., Nakajima, T. \& Tonooka, T. (2008). Effect of nitrogen application at anthesis on FHB and mycotoxin accumulation in breadmaking wheat in the western part of Japan. Journal of General Plant Pathology, 74(5), 355-363. https://doi.org/10.1007/s10327-008-0109-1

\title{
UTJECAJ RAZLIČITIH SUSTAVA KONZERVACIJSKE OBRADE TLA I GNOJIDBE DUŠIKOM NA INFEKCIJU ZRNA PŠENICE VRSTAMA Fusarium
}

\begin{abstract}
SAŽETAK
U radu je prikazan utjecaj različitih konzervacijskih sustava obrade tla i različitih razina gnojidbe dušikom na zarazu zrna pšenice vrstama Fusarium. Pokus je postavljen na dvije lokacije s pet sustava obrade tla: konvencionalna obrada s oranjem do $30 \mathrm{~cm}$, podrivanje na dubinu 35-40 cm, rahljenje do $25 \mathrm{~cm}$, tanjuranje na 10-15 cm i te direktna sjetva bez ikakve obrade tla, kao i s tri razine gnojidbe dušikom: N1- umanjena za 30\% u odnosu na preporuku; N2 - prema preporuci i N3 - uvećana za 30\% u odnosu na preporuku. Pojava zrna zaraženih vrstama Fusarium utvrđena je u svim istraživanih tretmana. Postotak zaraženih zrna vrstama Fusarium bio je statistički značajno niži na tretmanu gnojidbe N1 u odnosu na varijante gnojidbe N2 i N3. Najniži postotak zaraženih zrna pšenice zabilježen je kod konvencionalne obrade tla u Magadenovcu i no tillage tretmana и Čačincima.
\end{abstract}

Ključne riječi: konzervacijska obrada tla, gnojidba dušikom, infekcija zrna pšenice, Fusarium sp. 
(Received on November 5, 2018; accepted on March 22, 2019 - Primljeno 5. studenoga 2018.; prihvaćeno 22. ožujka 2019.) 